\title{
Research on the Issue of Education of ideality and Faith for Contemporary College Students
}

\author{
Sun Lidong ${ }^{1, \mathrm{a}}, \mathrm{Wu} \mathrm{Si}^{2, \mathrm{~b}}$ \\ ${ }^{1}$ Tianjin Polytechnic university, School of economics, Tianjin, 300387, China \\ ${ }^{2}$ Tianjin normal university, Elementary education college, Tianjin, 300387, China \\ aemail:252206992@qq.com, bemail:wusi1226@163.com
}

Keywords : Contemporary college students; ideality and faith; Education research

\begin{abstract}
Ideality and faith education is one of the important issues for the college students' ideological and moral cultivation. College students in current generation are in the multi-cultural era while in the special growing period. Therefore, several problems of ideality and faith for current generation students exist, based on which, we propose a few manners and strategies to solve these problems.
\end{abstract}

\section{Introduction}

Contemporary college students undertake the hope of country and nation, bearing the families and loved ones of entrust, they are full of the good life yearning for the future. Under the new historical conditions, they shoulder the task of the comprehensive construction of well-off society and realization of the great rejuvenation of the Chinese nation, a sacred mission of the Chinese dream. It is a critical period for contemporary college students' formation and establishment of ideality and faith. They not only should improve their theoretical and professional level, but also should strength their scientific conviction and understand the root of becoming a good person. Scientific ideality and faith education can guide students what kind of person they want to be, what kind of road they should take and what knowledge they should learn. Therefore, the ideality and faith education of college students is particularly important. The strength of college students' ideality faith education is in relation to our country's socialist modernization.

\section{The current situation of college students' ideality faith}

\subsection{Weakness of the psychological quality and lack of ideality faith firmness}

Contemporary college students are in a social environment of complex and profound changes, these changes bring college students both a rare opportunity and broad space, but it also made contemporary college students confront with huge pressure, including economic pressure, employment pressure, psychological stress and emotional stress, etc. During this period, students often cannot have a correct view of themselves and when faced with setbacks in life, they will generate pessimism, give up their pursuit, escape from reality, and some even have the idea of suicide. Due to the relatively stable development of the contemporary western capitalist countries, socialist ideality is relatively at a young age. This makes students lose confidence in socialism, and even question the superiority of socialism, doubt about the leadership of the communist party of China, and wave the confidence of socialism with Chinese characteristics.

\subsection{Excessive pursuit of personal ideality and individual differences}

For contemporary college students, talking about social ideality and personal choice, more and more people choose the personal ideality, and even some college students think that "the purpose of life is to have a satisfactory job and have a happy family, do a good job, be an upright person", and few students choose such as "struggle for the communist cause, to study for the revitalization of the Chinese, contribute to society and benefit the nation". In front of the low employment rate of the whole society, faced with crisis of unemployment after graduating from college, even under this 
kind of the reality conditions, many college students don't want to link their own ideality and serving the west development together, they would rather find an unsuitable job in the big cities.

\section{The causes of the deviation of ideality and faith}

\subsection{The influence of social factors}

First, with the deepening of reform, the diversification of the composition of economy and the economic interests, social life style, social organization form, jobs and employment form, etc, is witnessing the unprecedented changes, on one hand, it benefits students' self-improvement consciousness, competition consciousness and the consciousness of innovation, entrepreneurship, promoting their ability to become useful and benefits their personal value, on the other hand, the pursuit of individual interests undermines the pursuit of common interests, thus some college students lack the spirit and conscious to serve the society. They tend to be more utilitarian in study, neglecting the cultivation of humanities.

Secondly, with the expansion of the process of our opening policy, Chinese interaction with other nation in politics, economy, science and technology, cultural exchanges are getting frequent. The single thought culture value system is replaced by multicultural consciousness content. In front of the complicated cultural style and pluralistic values, many college students get into a confused plight in ideality cognitive, faith and beliefs. The pursuit of ideality and faith are more practical, paying more attention to real benefit.

\subsection{Contemporary college students' own factors}

First, contemporary college students is generally the "95 ", they are mostly grown up after the policy of reform and opening, and most of them are the only one and the most beloved ones in their families, which means they rarely suffer hardships. Meanwhile, affected by the exam-oriented education, students think their main task is to study, thus they are easily form a selfish, arrogant, a defiant mentality. Therefore they tend to ask for everything instead of offering something, meanwhile, they also enjoy temporary joy and reluctant to work hard which will inevitably reflected in their values of life and ideality and faith.

Secondly, in life and career, contemporary college students' independence and autonomy are gradually strengthen, as well as their self-cultivation and the ability to choose their own development goal and establish the ideality and faith. But most of the young students lack of life experience. In this period, their world outlook, the outlook on life, the values are forming steadily, some students believe too much in their own ideality and faith, and refused to accept correct education meanwhile some students rely too much on part of the environment and lack independence and autonomy.

\subsection{The Setbacks of Education Mechanism}

First, a common course of ideological and political theory education lack of effectiveness. A survey shows that $40 \%$ of the students think the thought political lesson useless, $60 \%$ of the students show no interest in this course, $34 \%$ of the students even don't know what the teacher are talking about, $66 \%$ of the students think that the way of teaching relate to the attitude of listening, $36 \%$ of the students think they hardly learn anything.

Secondly, a common course of ideological and political theory lack of pertinence and effectiveness of content. Most teachers take the Marxism as a dogmatic teaching to some extent, repetitive content is useless for college students' personal beliefs and social ideality and faith lacks pertinence and effectiveness. The lag of teaching ideas and single and old teaching means and methods regardless of the social reality and the actual needs of college students, giving students the feeling of the "void" on the ideality and faith.

\subsection{The Negative influence of network culture}

First, the application and popularization of network provide a variety of information for college students. Openness and convenience and the diversity and universality as the most impressive 
character, also provide a broad space and route for contemporary college students learning. However, some bad information on the network may cause the lack of beliefs or the pluralism of values among contemporary college students, influencing them to set up the correct outlook on life and values.

Secondly, the character of anonymity in the spreading and accepting of internet information is also likely to weaken the moral ideology as well as social sense of responsibility among teenagers,; Network communication are anonymous and bondless, which are easily leading college students to commit something violating the social conventions, and even to commit crimes.

Thirdly, surfing the Internet for a long time can cause a lack of communication with others among contemporary college students. Thus college students are liable to feel lonely, be indifference to interpersonal emotion, and be a escaper towards the real society. On the other hand, it may cause online love affair, which will trigger a series of emotional entanglements, thus leading to a variety of emotional problems. The anonymity and concealment also causes dual personality disorder and Internet addiction, thus leading students to be more lonely, sensitive, moody, alert and so on; they tend to do not obey the social norms, even have the abnormal behavior such as: mental disorders, suicide, etc., and these must shock the establishment of lofty ideality.

\section{Countermeasures to strengthen the ideality and faith education}

\subsection{Build solid theoretical foundation of the ideality and faith education}

First, we should firmly believe that socialism will replace the capitalist according to historical development trend. We should follow the guidance of Marxism-Leninism and Mao Zedong thought, Deng Xiaoping theory and "three represents" important thought and the scientific outlook on development, and research deeper on the big changes among socialism and capitalism in the 20th century, and scientifically admit that the contemporary capitalism will continue to survive and develop for a long time, however it will eventually be replaced by the socialist society considering its basic contradiction are incompatible. While socialism which is represented by Chinese characterized socialism, shows greater vigor in the future and will eventually replace the former regime.

Secondly, we should firmly believe the development direction of Chinese characterized socialism. Using the Marxism-Leninism and Mao Zedong thought, Deng Xiaoping theory and "three represents" important thought, the concept of scientific development as a guidance to help college students to understand the fate and the future of the country, to clarify the erroneous ideas of socialism and fuzzy understanding, and firmly stand by s Chinese characterized socialism.

Thirdly, scientifically understand new change and trend of the contemporary world by analyzing scientifically and understanding correctly of this changes and trends. In contemporary western world, in addition of Marxist, there are also some other scholars who are dedicated to study and reveal the contradiction of contemporary capitalism. We should identify and absorb the reasonable factors of these theory and valuable ingredients to promote the development of the theory of Marxism; and shouldn't use them to replace the historical materialism and scientific socialism by copying them without any deep analysis.

\subsection{Broadening the way of ideality and faith education}

First, change teaching directly into interaction, the ideality and faith education should not only reflect the dominant position of teachers, even should give full play to the subjective initiative of college students' consciousness and make them actively involved in the education work roundly, through the "interaction" between teachers and students, we can achieve the effect of unification, cohesion.

Secondly, work together. In order to improve college students' ideality and faith education, we must establish and improve a set of effective, standardization and institutionalization of the ideality and faith education mechanism; we should utilize all aspects and work together. To improve the teaching quality of ideality and faith education, we must combine it with the school's other work 
tightly. The key of "Combination" is to organize and guide, that is build a good environment, provide instructive, leading ideas, and provide a large number of facts to firm beliefs and direction for the college students' self education and self improving.

Thirdly, change the way of infusion to penetration, the ideality and faith education cannot be satisfied by the way of teaching, and we should pay more attention to infiltrate by using rich and practical education resources, inventing various kinds of teaching style to educate students imperceptibly.

\subsection{Strengthen the ideality and faith education in the process of teaching}

First, pay attention to and strengthen the management of classroom discipline, teachers must not only mind themselves without considering the audience. At the same time, schools should introduce corresponding hard measures and iron rule.

Secondly, achieve teaching and learning through interactive teaching, considering the need of teaching and learning. Every student in the class have the right to put forward questions they interested, teachers when teaching should consider the actual reality, actively answer students' questions and confusion, and help students to think deeply about the problems of the reality.

Thirdly, take efforts to break the traditional teaching mode, before class the teacher can send related courseware data to the student through electronic mail, letting the student divided into several groups freely, and each group must do presentation in class, and talk about their study and the experience of thinking and understanding, they also can communicate and debate, in this way, it not only can expand own aspect of knowledge and insight, but also can bring inspiration. Thus fully arouse the enthusiasm of teachers and students, so as to achieve the expected teaching effect.

Fourthly, use diverse forms to test students' learning situation. course assessment form are not limited to exam and paper, we also can explore test and try hard through practice, there are ways to show their ability, such as shooting, recording image related learning theory in the real life and put forward their own views, or writing social-related report, even poems, essays, speeches, and other forms of literature and art can also express their views and opinions.

\subsection{Create a sound environment for college students' ideality and faith education}

First, Chinese communist party member should act as an example, thus we should pay more attention to these students education and cultivation, especially for those who join into this party in a short time, enhancing their personal ability as well as quality, in order to make them feel more responsible to play an exemplary role. Meanwhile we should enhance our communist party's influence and power on college students, and constantly strengthen the guide of college students' ideology, organization and team training.

Secondly, we should strengthen the construction of civic virtues and spirits and create a good environment, and conscientiously implement the party's education policy, implementing quality education fully, combining teaching with education closely. Planning different content of moral education in different learning phase scientifically, and adhering to the students' daily behavior standards; strengthening the construction of the secondary school spirit. Meanwhile teachers should play an exemplary role to show moral education in every step of school education. Every teacher should be a good demonstration for students. Only if a teacher can be aspired, school education can be successful.

\subsection{Guide students to understand themselves correctly and have a positive self-efficacy}

College students' correct understanding of self and have a positive self-efficacy is the premise to establish ideality belief. To know him self correctly is to understand their own individual inclination and individual mental characteristics, college students can know others to know him self, by analyzing the results of his activities and self-observation. Thus one can be independent development, independent choice, self evaluation and self control. Meanwhile we should help college students to discover their own potential, regarding them as the main body of understanding and practicing activities. Make their initiative, autonomy and subjectivity of potential play a further 
role by leading college students to participate in the process of the ideality and faith education based on their own development characteristics.

\subsection{Expand the network space of belief education in colleges}

We should capture network ideality and faith education position actively. With the rapid development of network information technology, the Internet has become a new important position of ideological and political education to cultivate the humanistic spirit, letting students fully understand that network is channels or media for information dissemination-the fourth media after newspaper, broadcast, TV. It is a double-edged sword, on one hand, it can bring people a wealth of useful information, on the other hand, can make people fall into the trap of network. Thus it is important to recognize all kinds of information and distinguish right from wrong on the network, absorbing its essence to its dregs, and consciously develop the correct ideality and faith of socialism.

\section{References}

[1] Xu Jianbao. College students' status and strengthen belief of college students belief education countermeasure research [J]. Journal of jiamusi institute proceedings, 2010 (4)

[2] Zhao Weina. Modern college students' ideality and faith education [J] practice and exploration, $2010(1)$

[3] Luo Danping. Introduction to college students' ideality and faith existence question and countermeasure [J]. Market weekly - theory research, 2009 (12) Leader

[4],hellmann. Under the multicultural background college students' ideality and faith education situation and deal with [J]. Journal of vocational space-time, 2010 (6)

[5] xiao-ming li. The thinking of college students' ideality and faith education [J]. Journal of front, 2010 (12) 